Jurnal Ilmiah Komunikasi

\title{
IDX Channel Sebagai Media Promosi Bursa Efek Indonesia Dalam Menginformasikan Berita Pasar Modal
}

\author{
Nurlina Aidha Shabrina ${ }^{1}$, Veronika Setyadji ${ }^{2}$ \\ ${ }^{1.2}$ Program Studi Diploma Periklanan \\ Sekolah Tinggi Ilmu Komunikasi Indonesia Maju \\ Jln. Harapan Nomor 50, Lenteng Agung - Jakarta Selatan 12610 \\ Telp: (021) 78894045, Email: ${ }^{1}$ nurlina.n160@gmail.com, ${ }^{2}$ veronika.stikom.14@gmail.com
}

\begin{abstract}
Abstrak
IDX Channel sebagai media penyebar informasi dan promosi resmi milik Bursa Efek Indonesia memiliki program siaran yang bervariasi seperti talkshow, informasi terbaru fluktuasi pasar modal hingga event untuk memberi pengetahuan dan menarik minat masyarakat serta menjadi salah satu cara untuk menambah jumlah investor muda di pasar modal yang nantinya akan membantu meningkatkan perekonomian Indonesia melalui investasi saham. Tujuan penelitian ini adalah supaya strategi promosi yang dilakukan Bursa Efek Indonesia dalam menginformasikan berita pasar modal melalui IDX Channel dapat mencapai sasaran yang tepat.Penelitian ini menggunakan metode deskriptif kualitatif dan bersifat studi kasus, yaitu peneliti mempelajari dan memahami objek penelitian dengan maksimal, dengan teknik pengumpulan data berupa observasi, wawancara mendalam kepada informanyang memiliki peran besar dalam penelitian ini, dan dokumentasi. Hasil penelitian ini menunjukan bahwa Bursa Efek Indonesia terus berupaya untuk semakin menyebarluaskan informasi seputar pasar modal melalui program dan event promosi yang dilakukan off air (seminar "Yuk Nabung Saham", "Galeri Investasi", "Sekolah Pasar Modal" dan "Stocksound") maupun on air (promo filler, iklan dan beberapa program seperti IDX Market Opening, Market Now, Top Stock, IDX $1^{\text {st }}$ Session Clossing, Market Headline,dan News Screen) di IDX Channel dan media partner lainnya yang semakin memudahkan pengusaha dan calon investor mendapatkan informasi seputar bisnis dan keuangan.
\end{abstract}

Kata Kunci :Bursa Efek Indonesia, IDX Channel, Promosi

\begin{abstract}
IDX Channel as a medium of information spreading and official promotion of the Indonesia Stock Exchange has a broadcast programs with varied content such as talk shows, up to date information on capital market fluctuations to events to provide knowledge and attract community interest and to be one way to increase the number of young investors in the capital market which will help improve the Indonesian economy through stock investment. The purpose of this research is so that the promotional strategies carried out by the Indonesia Stock Exchange in informing capital market news through IDX Channel can reach the right target.This research uses qualitative descriptive method and case study, that is the researcher studies and understands the object of research maximally with data collection techniques of observation, in-depth interviews to informantswho played a major role in this research, and documentation.The result of this study indicate that the Indonesia Stock Exchange continues to strive to further spreading information about the capital market through promotional programs and events conducted off air (Yuk Nabung Saham" workshop, "Galeri Investasi", Sekolah Pasar Modal", and "Stocksound") and on air (filler promo, advertisements and several programs such as "IDX

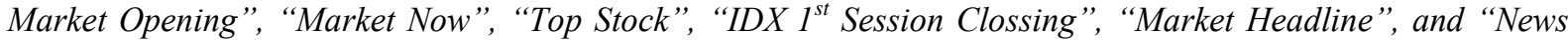
Screen") on IDX Channel and other media partners that make it easier for entrepreneurs and potential investors to get information about business and finance.
\end{abstract}

Keyword :Indonesia Stock Exchange, IDX Channel, Promotion 


\section{Pendahuluan}

Bursa Efek Indonesia merupakan gabungan dari Bursa Efek Jakarta dan Bursa Efek Surabaya, berfungsi untuk mewadahi kegiatan penawaran dan perdagangan efek (saham) dengan melibatkan perusahaan publik serta lembaga terkait yang telah tergabung dan tercatat didalam pasar modal (emiten). Informasi tentang kegiatan perdagangan efek, transaksi saham, harga saham dan fluktuasi yang terjadi di pasar modal tersedia di berbagai media untuk memudahkan pengusaha, calon investor dan masyarakat umum supaya mengetahui lebih detail kabar terkini pasar modal Indonesia.

Penyebarluasan informasi pasar modal tersebut dilakukan melalui kegiatan pemasaran yang sudah pasti dilakukan oleh perusahaan penjual produk maupun jasa, karena pemasaran merupakan sebuah proses kemasyarakatan dimana individu dan kelompok memperoleh apa yang mereka butuhkan dan inginkan dengan menciptakan, menawarkan, dan secara bebas mempertukarkan produk dan jasa yang bernilai dengan orang lain. ${ }^{1}$

Hal tersebut seperti saham - saham perusahaan yang tercatat di pasar modal untuk individu maupun kelompok organisasi yang nantinya akan saling melakukan transaksi dalam melakukan pembelian serta penjualan saham yang mereka miliki, sehingga dibutuhkan peran seluruh anggota perusahaan supaya hal - hal yang menjadi visi dan misi Bursa Efek Indonesia tercapai.

Pemasaran juga bertujuan untuk meningkatkan citra dan nilai jual sebuah perusahaan Bursa Efek Indonesia yang selalu berupaya memperkenalkan pasar modal kepada masyarakat luas khususnya kalangan muda yang masih awam mengenai dunia pasar modal supaya mau belajar dan mengenal cara berinvestasi dan menabung selain dengan menabung uang di bank yaitu dengan pembelian atau tabungan berupa saham di pasar modal.

Pemasaran pada perusahaan akan semakin efektif dengan empat (4) unsur pendukung yang terdapat pada bauran pemasaran yang merupakan strategi mencampurkan kegiatan kegiatan marketing, agar dicari kombinasi maksimal sehingga mendatangkan hasil paling memuaskan. ${ }^{2}$ Empat (4) unsur bauran pemasaran tersebut seperti product (produk) bukan hanya benda yang berwujud melainkan benda yang tidak berwujud seperti jasa yang akan dipasarkan oleh perusahaan, price (harga) menjadi salah satu unsur yang perlu diperhatikan dalam pemasaran agar penentuan harga tepat sasaran sesuai dengan target pasar perusahaan,kemudian place (tempat) berupa penempatan produk atau jasa perusahaan yang akan dipasarkan, sama halnya dengan harga, penempatan pasar juga harus sesuai dengan target market yang diinginkan perusahaan agar hasil penjualan maksimal.

Unsur berikutnya yaitu promotion (promosi). ${ }^{3}$ Hal - hal tersebut tentunya tidak bisa dipisahkan dari kegiatan pemasaran yang dilakukan oleh sebuah perusahaan, karena promosi merupakan kegiatan penjualan dan pemasaran dalam rangka menginformasikan dan mendorong permintaan terhadap produk, jasa, dan ide dari perusahaan dengan cara memengaruhi konsumen agar mau membeli produk dan jasa yang dihasilkan oleh perusahaan. ${ }^{4}$

Bursa Efek Indonesia yang mewadahi kegiatan transaksi jual beli saham emiten yang tergabung didalamnya serta sumber informasi pasar modal para pengusaha dan investor juga melakukan promosi yang dikhususkan untuk memasarkan jasa perusahaannya, karena promosi jasa itu sendiri merupakan jasa atau layanan yang aktivitasnya melibatkan sejumlah interaksi dengan konsumen atau dengan barang - barang tetapi tidak memiliki transfer kepemilikan. ${ }^{5}$

Promosi juga memerlukan langkah yang tepat atau strategi supaya pesan promosi dapat diterima dengan baik oleh masyarakat. Salah satunya dengan memperhatikan kombinasi strategi yang paling baik sebagai alat komunikasi dengan konsumen ataupun calon konsumen yang terdiri dari sales promotion atau promosi penjualan ( berupa insentif atau bonus jangka pendek yang bertujuan untuk menunjang pembelian dan diberikan dalam bentuk discount, coupons, displays, demonstrations, contests, sweepstakes, events dan lainnya), kemudian 
personal selling atau penjualan perseorangan (yaitu penjualan yang dilakukan oleh seorang tenaga penjual yang langsung memberikan presentasi atau penjelasannya untuk konsumen melalui promosi yang biasa digunakan seperti presentations, trade show dan incentive program), kemudian ada public relation atau hubungan masyarakat (memiliki tujuan untuk membangun citra serta hubungan yang baik dengan publik perusahaan melalui bentuk promosi seperti press releases, sponsorship, special events serta web pages), selanjutnya direct marketing atau penjualan langsung (merupakan hubungan langsung dengan konsumen supaya dapat mengetahui respons konsumen sesegera mungkin yang dapat dilakukan melalui catalogs, telephone marketing, internet, mobile marketing dan lainnya). Strategi selanjutnya yang juga sangat berpengaruh yaitu advertising yang merupakan bentuk promosi yang dianggap sebagai manajemen citra dan bertujuan untuk menciptakan dan memelihara cipta yang mencakup broadcast, print, dan lainnya. ${ }^{6}$ Manajemen citra yang dimaksud dalam periklanan merupakan cara untuk membuat pandangan masyarakat terhadap perusahaan ataupun produk yang dipromosikan sesuai dengan pesan dan informasi yang disampaikan dalam beriklan.

Promosi melalui periklanan baik itu melalui media cetak maupun elektronik juga dianggap lebih unggul dan cukup efektif karena dapat menjangkau semua kalangan masyarakat karena iklan memiliki tampilan yang lebih menarik dan menghibur dibanding media promosi lainnya, dengan penggunaan beberapa aspek pendukung seperti warna, tulisan, suara, gambar, serta pesan yang menarik perhatian karena menggunakan bahasa yang ringan akan lebih mudah dimengerti oleh masyarakat luas sehingga pesan sebuah iklan dapat tersampaikan dengan baik dan tidak menimbulkan perbedaan dalam mengartikan iklan tersebut.

Iklan juga terbagi menjadi kedalam beberapa jenis seperti iklan konsumen (bertujuan untuk mempromosikan barang - barang konsumsi umum dimasyarakat seperti iklan makanan), iklan antar bisnis (untuk mempromosikan barang atau jasa non konsumen seperti iklan bahan mentah dan mesin), iklan perdagangan (khusus ditujukan untuk kalangan distributor, pedagang, agen seperti, iklan eceran (dibuat dan dibiayai oleh pemasok atau perusahaan ditujukan untuk pengecer), iklan rekrutmen (untuk merekrut calon pegawai untuk dipekerjakan seperti iklan lowongan kerja di koran), dan iklan keuangan yang meliputi iklan bank, jasa tabungan, asuransi dan investasi. Tujuan iklan keuangan adalah untuk menghimpun dana pinjaman dan menawarkan modal, baik dalam bentuk asuransi, penjualan saham, surat obligasi, surat utang atau dana pensiun. ${ }^{7}$ Periklanan jenis ini tentunya sesuai dengan perusahaan Bursa Efek Indonesia yang bergerak di bidang keuangan.

Iklan tentu memerlukan media sebagai sarana untuk mengkomunikasikan pesan promosi. Media yang dapat digunakan dalam beriklan yaitu televisi, radio, koran, majalah, tabloid, dan sebagainya (above the line), serta media lain seperti brosur, buklet, katalog hingga event (below the line). ${ }^{8}$ Penggunaan media sebagai alat promosi juga dapat membantu penyampaian pesan supaya lebih efektif kepada masyarakat sehingga masyarakat mengetahui tujuan iklan yang disampaikan. Seperti Bursa Efek Indonesia yang memilih menggunakan media televisi sebagai sarana utama untuk melakukan promosi dan penyebaran informasi kepada khalayak melalui IDX Channel.

IDX Channel menayangkan program yang tidak jauh berbeda dengan televisi khusus seputar ekonomi dan bisnis lainnya yaitu seputar pasar modal dengan target utamanya adalah pengusaha dan para professional dibidangnya, melalui berbagai jenis program seperti hard news (informasi terkini yang disiarkan dalam laporan berita), soft news (informasi yang disampaikan mendalam seperti talkshow). ${ }^{9}$ Hingga program hiburan seperti "Stocksound" yaitu event musik rutin Bursa Efek Indonesia yang diadakan setiap akhir bulan bertepatan dengan penutupan pasar modal, program yang ditayangkan secara langsung di IDX Channel ini juga sebagai ajang promosi untuk menarik minat anak muda menyaksikan program seputar pasar modal melalui kehadiran penyanyi terkenal di setiap eventnya yang dapat disaksikan di beberapa saluran televisi berbayar seperti 
Indovision, MNC Play, First Media, dan Okevision.

Melalui berbagai tayangan di IDX Channel, diharapkan masyarakat Indonesia akan semakin peduli terhadap dunia bisnis dan ekonomi di Indonesia sehingga semakin banyak orang yang mau berinvestasi di pasar modal dan akan berdampak untuk kemajuan perekonomian di Indonesia.

\section{Metode}

Metode yang digunakan dalam penelitian ini adalah deskriptif kualitatif yang bertujuan untuk mengetahui tentang program strategi promosi Bursa Efek Indonesia dalam menginformasikan berita pasar modal melalui IDX Channel. Menurut Bogdan \& Taylor, metodologi kualitatif merupakan prosedur penelitian yang menghasilkan data deskriptif berupa kata- kata tertulis atau lisan dimana metode yang digunakan menekankan pada proses penelusuran data atau informasi hingga dirasakan telah cukup digunakan untuk membuat suatu interpretasi. ${ }^{10}$ Sesuai dengan penelitian ini yang penelusuran data dan informasi tentang promosi dan informasi pasar modal dilakukan di Bursa Efek Indonesia dan IDX Channel.

Penelitian ini bersifat studi kasus dengan pokok pertanyaan yang berkenaan denganhow (bagaimana) dan why (mengapa). ${ }^{11}$ Karena strategi pertanyaan bagaimana dan mengapa dirasa mampu menjelaskan fenomena yang terjadi pada penelitian lebih dalam lagi.

Penelitian jenis ini juga tidak menggunakan kuesioner sebagai instrumen pengumpulan data melainkan dengan pedoman wawancara, karena pengumpulan data dilakukan oleh peneliti itu sendiri melalui tahap observasi, bertujuan untuk lebih dekat kepada objek penelitian dan informan yang akan menjadi sumber informasi penelitian ini.

Tahap selanjutnya yaitu dengan melakukan wawancara untuk mendapatkan informasi lengkap dan akurat terkait dengan objek yang diteliti. Pada tahap ini, pemilihan informan berdasarkan pengetahuan hingga kontribusinya seputar kegiatan promosi dan penyebaran informasi pasar modal melalui IDX Channel, hingga terpilih 3 (tiga) orang yaitu Head of
Communication and Public Information Unit Corporate Secretary Bursa Efek Indonesia yang mengetahui dari awal proses promo untuk program dan event yang dilakukan Bursa Efek serta publikasinya melalui berbagai media dan Senior Promo ProducerIDX Channel yang mengemas promo on-air untuk program Bursa Efek mulai dari pembuatan konsep hingga siap ditayangkan di saluran televisi IDX Channel dirasa mampu memberikan informasinya terkait objek yang diteliti serta Vice President PT. Valbury Sekuritas, salah satu trader di Bursa Efek Indonesia yang berbagi pengalaman selama menjadi trader di Bursa Efek Indonesia sekaligus tanggapan mengenai pentingnya kehadiran IDX Channel sebagai sumber informasi utama seputar bisnis dan keuangan untuk pengusaha sepertinya. Kebutuhan data dapat dilengkapi dengan adanya dokumentasi yang diperoleh dari buku, internet hingga foto untuk memperkuat data yang ada.

Penelitian dilakukan di redaksi IDX Channel gedung Inews Center, Jalan Kebon Sirih Kav. 17-19 Jakarta Pusat dan Bursa Efek Indonesia Jalan Jend. Sudirman Kav. 52 -53, Jakarta 12190 dengan periode waktu dari bulan Maret hingga Mei 2017.

Analisis data yang dilakukan untuk mengolah informasi yang sudah didapat pada penelitian ini melalui beberapa proses yaitu reduksi data yang merupakan proses memilih dan menyederhanakan informasi mana yang sesuai dan tidak sesuai dengan topik penelitian sehingga data akan lebih mengerucut dan fokus kearah inti pembahasan. Kedua, proses penyajian data berupa uraian yang bersifat deskriptif dan juga dalam bentuk tabel yang semakin mempermudah penjelasan mengenai informasi penelitian.Proses terakhir yaitu penarikan kesimpulan untuk merumuskan makna dari hasil penelitian yang diungkapkan dengan kalimat yang mudah dipahami, kemudian dilakukan peninjauan kembali untuk memastikan kebenaran data berkaitan dengan relevansi dan konsistensinya dengan judul, tujuan dan rumusan masalah yang ada. ${ }^{12}$ Reduksi data dilakukan saat hasil wawancara, dokumentasi dan beberapa sumber lainnya seperti dari buku telah terkumpul, kemudian penyajian data yang berisi fenomena yang telah 
diteliti selama proses pengumpulan data untuk menjelaskan proses promosi dan penyebaran informasi dilakukan oleh pihak Bursa Efek Indonesia dan IDX Channel.

\section{Hasil dan Pembahasan}

Bursa Efek pertama kali dibentuk di Indonesia pada tahun 1912 oleh Pemerintah Hindia Belanda karena secara historis, pasar modal di Indonesia telah hadi pada zaman kolonial Belanda untuk kepentingan pemerintahan kolonial atau $V O C$.

Meskipun pasar modal telah ada sejak tahun 1912, perkembangan dan pertumbuhan pasar modal tidak berjalan seperti yang diharapkan, bahkan pada beberapa periode kegiatan pasar modal mengalami kevakuman.Hal tersebut disebabkan oleh beberapa faktor seperti perang dunia ke I dan II, perpindahan kekuasaan dari pemerintah kolonial kepada pemerintah Republik Indonesia, dan berbagai kondisi yang menyebabkan operasi bursa efek tidak dapat berjalan sebagaimana adanya.

Pemerintah Republik Indonesia mengaktifkan kembali pasar modal pada tahun 1977, dan beberapa tahun kemudian pasar modal mengalami pertumbuhan seiring dengan berbagai insentif dan regulasi yang dikeluarkan pemerintah, untuk itu IDX Channel sebagai televisi resmi Bursa Efek Indonesia hadir bertepatan dengan 38 (tiga puluh delapan) tahun diaktifkannya kembali pasar modal di Indonesia. $^{13}$

IDX Channel sebagai satu - satunya televisi yang secara lengkap menyiarkan berita pasar modal di Indonesia yang siarannya dilakukan langsung dari gedung Bursa Efek Indonesia ini dapat disaksikan di saluran tv berbayar seperti Indovision, Top Tv dan lainnya, maupun secara streaming melalui www.okezone.tv dan www.sindonews.com

Program yang disajikan juga bervariasi seperti berita yang berisi informasi pasar modal, talkshow dengan narasumber sesuai topik yang berkaitan dengan pasar modal, narasumber merupakan analis saham, investor hingga pengusaha yang sahamnya tercatat di Bursa Efek Indonesia dan dipilih berdasarkan topik yang akan dibahas lalu ada magazine yang berisi informasi bisnis dan keuangan dari mancanegara, selain itu ada program berisi talkshow dengan tokoh - tokoh sukses dan menginspirasi di bidangnya yang hadir setiap hari.

IDX Channel memiliki visi yaitu turut membantu dan bekerja sama dengan BEI dalam mensosialisasikan investasi di pasar modal, dan memberikan pemberitaan seputar ekonomi dan bisnis dalam dan luar negeri. Serta misi yaitu menjadi channel bisnis terbesar di Indonesia dan menjadi referensi perkembangan capital market di Indonesia untuk investor domestik dan luar negeri. ${ }^{14}$

\section{IDX Channel Sebagai Media Informasi dan Promosi Pasar Modal Resmi BEI}

Media televisi saat ini berkembang sangat pesat dan jangkauannya yang luas dirasa mampu menyiarkan informasi dengan lebih efektif. Tayangan televisi juga dapat disaksikan dari berbagai profesi dan status sosial yang berbeda mulai dari anak - anak, remaja, pelajar, ibu rumah tangga, hingga kalangan pengusaha dapat menyaksikan program siaran yang beragam di televisi sesuai dengan kebutuhan masing masing individu. Hal tersebut yang membuat Bursa Efek Indonesia semakin yakin memilih untuk melakukan penyebaran informasi dan promosi melalui media televisi resminya, yaitu IDX Channel.

Program siaran yang ada di IDX Channel juga sangat bervariasi dan up to date (aktual) antara lain ; "Market Sight" yang berisi buletin info makro ekonomi, sesi telepon dengan analis saham dan evaluasi harga saham, program "Market Opening" berisi talkshow pra pembukaan pasar, review pasar dan proyeksi harian selama jam perdagangan berlangsung. "Market Now" berisi talkshow tentang isu pasar saham terkini, topik tentang perusahaan yang melakukan pencatatan di bursa saham dan prospek bisnis dengan tamu dari pembukaan pasar. "Top Stock" berisi talkshow dengan para $C E O$ tentang update pencatatan perusahaan dan strategi bisnis, pembahasan kinerja bisnis perusahaan dan perseroan Negara (PT). "IDX Clossing $I^{\text {st }}$ Session" berisi tinjauan jam perdagangan sesi pertama, analisa pergerakan 
saham, talkshow dengan podium untuk analyst battle. "Market Headline" berita bisnis berbahasa inggris, meliputi update perusahaan tercatat, berita perusahaan global terkini beskala lokal dan internasional. "Brief to $2^{\text {nd }}$ Session" berisi talkshow dengan pergerakan saham, isu dan tren harian di pasar domestik dan global, serta penjelasan singkat untuk investor tentang saham yang bagus di sesi berikutnya.Kemudian ada "Top Stock 2" berisi tentang kinerja bisnis perusahaan dan keuangan perseroan negara, serta interaksi dengan market player melalui telepon atau sms. "IDX Clossing Market $2^{\text {nd }}$ Session" talkshow pasar modal selama 1,5 (satu setengah) jam, membahas pasar terbaru, analis ekonomi dan perusahaan terdaftar dengan judul utama Analis Pergerakan Saham dan Berita Bisnis. Serta "News Screen" berisi buletin berita, informasi makro ekonomi dan sektor riil serta menghadirkan isu ekonomi yang semuanya dibutuhkan dansangat dirasakan manfaatnya terutama oleh trader (orang yang melakukan jual beli di pasar saham) yang sangat membutuhkan setiap informasi terkini yang IDX Channel sajikan.

Program - program tersebut ditayangkan langsung secara regular setiap hari Senin sampai dengan Jum'at mulai pukul 07.30 hingga 18.00 WIB ditambah beberapa program yang disaksikan secara taping (rekaman). Selain itu IDX Channel juga memiliki program khusus yang hanya ditayangkan setiap akhir pekan. Program - program tersebut tentunya lebih mengarah ke soft news hingga hiburan yang lebih ringan dibanding program yang disiarkan selama weekdays, seperti "Titanium" berisi berbagi kisah sukses orang - orang terkemuka hingga organisasi dan perusahaan, kemudian "Special Report" berisi buletin berita selama satu minggu tentang event ekonomi, selanjutnya "Summary \& Outlook" berisi dialog saham, analisis perdagangan minggu sebelumnya dan prediksi pasar modal, Terakhir ada "Special Dialogue" berisi talkshow tentang investasi, profil perusahaan, isu - isu ekonomi, dan lain sebagainya.

Penyebaran informasi bisnis, keuangan dan pasar modal yang ada melalui program regular tersebut yang menghadirkan berita up to date dan berimbang untuk dapat disaksikan oleh masyarakat tentu merupakan bagian dari kerja keras para team yang terlibat didalam proses produksinya, mulai dari pasca produksi yang kegiatannya dilakukan di redaksi IDX Channel lantai sembilan (9) gedung Inews Center dan redaksi IDX Channel sekaligus studio untuk live news yang berkator di gedung Indonesia Stock Exchange kawasan bisnis SCBD. Tahapan yang dilakukan yaitu mulai dari pencarian berita yang dilakukan oleh producer dan production assistant melalui liputan langsung hingga info yang didapat dari koran bisnis mancanegara mengenai bisnis dan ekonomi yang topiknya relevan untuk diangkat menjadi sebuah tayangan berita di IDX Channel. Selanjutnya bahan berita yang sudah ada diolah kedalam sebuah rundown sesuai program yang akan disiarkan menjadi beberapa jam sebelumnya, naskah berita dibagi menjadi beberapa segmen yang sudah ditentukan oleh producer.

Tahap selanjutnya yang dilakukan production assistant setelah rundown program selesai dibuat yaitu membuat naskah untuk teleprompter yang akan digunakan oleh news anchor (pembaca berita) sebagai acuan saat siaran berita dilakukan, hal ini dilakukan bersamaan dengan divisi editor dan divisi grafis yang bertugas memasukan gambar, video serta bagan grafis fluktuasi saham yang disorder berdasarkan segmen berita yang akan ditayangkan didalam rundown, gambar, video serta grafis harus sesuai dengan segmen berita agar tayangan berita mudah dimengerti oleh masyarakat. Setelah semua tahapan tersebut selesai, production assistant mengirimkan naskah prompter dan rundown melalui email kepada producer yang sedang bertugas melakukan on air di studio, yang kemudian akan diberikan kepada team lain yang bertugas melakukan on-air.

Bursa Efek Indonesia tentunya juga memiliki strategi untuk menginformasikan kegiatannya yang berkaitan dengan pasar modal dan program yang sedang dilaksanakan kepada masyarakat melalui IDX Channel sehingga promosi sudah pasti dilakukan untuk penyebaran informasi tersebut.

Pembuatan promo berkala baik itu iklan program regular maupun periklanan atau 
promosi dalam bentuk filler (liputan) tentu dilakukan IDX Channel melalui divisi promosinya, seperti pembuatan filler promo program "Yuk Nabung Saham" yang berisi cuplikan seminar di beberapa kampus dan tanggapan beberapa mahasiswa yang telah bergabung di pasar modal melalui program tersebut mengenai keuntungan yang mereka dapat agar dapat menjadi contoh untuk anak anak muda lainnya dengan durasi sekitar 30 (tiga puluh) sampai 120 (seratus dua puluh) detik.

Divisi promosi IDX Channel melakukan beberapa tahap sebelum promo on-air dibuat, seperti melakukan koordinasi dengan pihak Bursa Efek Indonesia yang programnya ingin di publikasi kepada masyarakat secara on-air, tujuannya adalah untuk mendiskusikan hal apa yang ingin di highlight dari program yang dipromosikan supaya pesan yang akan dibuat sesuai dengan yang ingin disampaikan kepada masyarakat. Setelahnya, divisi promosi IDX Channel membuat konsep promo yang akan ditayangkan, mulai dari mengemas naskah iklan, pembuatan story board, pemilihan talent dan hal - hal teknis lainnya yang disesuaikan dengan materi promo dari pihak Bursa Efek Indonesia. Proses promosi ini juga memiliki kendala pada jarak dan waktu karena divisi promo IDX Channel yang menempati redaksi di gedung Inews Center kawasan Kebon Sirih harus melakukan meeting dengan pihak Bursa di tempat yang berbeda yaitu di gedung Indonesia Stock Exchange kawasan Sudirman, namun kendala tersebut masih bisa diatasi dan tidak menghambat proses promosi yang dilakukan.

IDX Channel melalui berbagai program on air maupun off air nya telah banyak berkontribusi untuk penyebaran informasi yang 80 (delapan puluh) \% nya berhubungan dengan pasar modal di Bursa Efek Indonesia. Penyebaran informasi dilakukan untuk memberikan pengetahuan tentang pasar modal kepada masyarakat dan tentunya memenuhi kebutuhan informasi para pengusaha dan investor tentang data akurat dan berimbang mengenai fluktuasi saham di pasar modal Indonesia.

\section{Promosi BEI untuk Mendukung Penyebaran Informasi Pasar Modal}

Bursa Efek Indonesia tentunya memiliki program - program unggulan yang digalakan selain program berita informasi dan promosi onair melalui IDX Channel.Program yang dibuat oleh Bursa Efek Indonesia yang bertujuan sebagai media penyebaran informasi dan promosi didominasi dengan event sehingga lebih banyak orang yang terlibat dan lebih menarik minat masyarakat.

Program tersebut salah satunya adalah event "Yuk Nabung Saham", kampanye yang diselenggarakan oleh PT Bursa Efek Indonesia (BEI) untuk mengajak masyarakat sebagai calon investor untuk berinvestasi di pasar modal dengan membeli saham secara rutin dan berkala. Kampanye ini dimaksudkan untuk mengubah kebiasaan masyarakat Indonesia dari kebiasaan menabung menjadi berinvestasi.Kampanye "Yuk Nabung Saham" ini diluncurkan pada tanggal 12 November 2015 oleh Wakil Presiden Republik Indonesia Bapak Muhammad Jusuf Kalla di Main Hall Gedung Indonesia Stock Exchange.

Event selanjutnya yang dibuat yaitu "Stocksound", merupakan event musik yang menampilkan penyanyi terkenal sebagai bintang tamu utamanya.Kegiatan ini dilakukan sebagai rangkaian kegiatan penutupan pasar modal yang diadakan setiap akhir bulan. Kegiatan ini juga termasuk kedalam salah satu rangkaian promo program "Yuk Nabung Saham" khususnya untuk menarik minat anak muda agar mau belajar menabung saham karena kegiatan ini dibuka untuk umum dengan syarat dan kententuan yang sudah diberlakukan oleh panitia penyelenggara program dan banyak anak - anak muda yang datang untuk menyaksikanevent yang diadakan di Main Hall gedung Bursa Efek Indonesia ini.

Bursa juga membuat program yang bersifat eduakasi seperti "Sekolah Pasar Modal (SPM)" dan "Sekolah Pasar Modal Syariah (SPMS)" adalah program edukasi dan sosialisasi pasar modal yang diselenggarakan secara berkala oleh Bursa Efek Indonesia (BEI).Seluruh masyarakat umum dapat menjadi peserta "SPM" dan "SPMS" sepanjang telah melakukan pendaftaran sesuai dengan syarat dan ketentuan yang berlaku.Tujuan utamanya diadakan sekolah pasar modal ini adalah untuk memberikan 
pengarahan dan edukasi tentang bagaimana caranya berinvestasi terutama untuk para pemula dan masih minim pengetahuannya tentang pasar modal.

Event atau program selanjutnya yaitu "Galeri investasi", merupakan sarana untuk memperkenalkan Pasar Modal sejak dini kepada dunia akademisi. "Galeri Investasi" BEI berkonsep 3 in 1 yang merupakan kerjasama antara BEI, Perguruan Tinggi dan Perusahaan Sekuritas diharapkan tidak hanya memperkenalkan Pasar Modal dari sisi teori saja akan tetapi juga prakteknya. Kedepannya melalui "Galeri Investasi" BEI yang menyediakan real time information untuk belajar menganalisa aktivitas perdagangan saham, diharapkan dapat menjadi jembatan menuju penguasaan ilmu pengetahuan beserta prakteknya di pasar modal. "Galeri Investasi" sudah tersebar ke lebih dari 200 (dua ratus) universitas yang ada di seluruh Indonesia seperti Universitas Gunadarma, Universitas Trisakti, Universitas Bina Nusantara, Universitas Diponegoro, dan lainnya. Galeri investasi ini juga memudahkan terutama kalangan mahasiswa yang ingin belajar tentang pasar modal karena sudah tersedia tempat tersedianya informasi pasar modal yang dapat dengan mudah dijangkau karena tersedia di beberapa kampus terkenal yang tersebar di hampir seluruh

Beberapa program dan event yang telah disebutkan sudah pasti ditayangkan promonya di saluran IDX Channel, selain itu Bursa Efek Indonesia juga bekerja sama dengan beberapa media partner sebagai alternatif media penyebaran informasi dan promosi pada setiap program yang sedang dilakukan mulai dari media televisi (Net TV, Inews TV, dan Metro TV), media radio seperti 90.00 Elshinta FM, dan media cetak dan media digital (online) seperti Okezone.com, Sindonews.com, Kontan.co.id, harian Kompas, Tempo dan beberapa media lain. Pemilihan media partner dilakukan karena keterbatasan tayangan IDX Channel yang hanya dapat disaksikan disaluran tv berbayar sehingga Bursa Efek Indonesia menambah media partner supaya penyebaran informasi pasar modal lebih menjangkau kalangan masyarakat luas.
Promosi yang giat dilakukan tersebut terbukti telah berhasil menambah jumlah investor yang ada di pasar modal saat ini, hal ini diperkuat dengan pernyataan salah satu informan yang menyatakan bahwa saat ini pemain saham baru diusia muda produktif seperti mahasiswameningkat hampir tiga puluh (30\%) jika dibandingkan dengan survey sebelumnya yang didominasi oleh korporasi asing, dan diharapkan supaya kedepannya semakin banyak masyarakat yang menyadari pentingnya investasi di pasar modal dilakukan untuk masa depan sehingga perekonomian di Indonesia juga dapat meningkat.

\section{Kesimpulan}

Bursa Efek Indonesia telah banyak melakukan upaya untuk membuat masyarakat menyadari betapa pentingnya investasi saham dilakukan seperti melalui media resminya yaitu IDX Channel yang berisi program reguler yang sangat informatif seperti pergerakan harga saham, talkshow bersama narasumber seputar dunia pasar modal bahkan promosi on-air untuk program atau kegiatan yang ada di Bursa Efek Indonesia selalu ditayangkan setiap harinya di IDX Channel. Promosi juga dilakukan melalui hampir semua media yang ada mulai dari tv seperti Metro TV, radio seperti 90.00 Elshinta FM, dan media online seperti Okezone.com untuk semakin menggencarkan penyebaran informasi dan publikasi program yang ada di bursa.

Promosi yang dilakukan Bursa Efek Indonesia sudah cukup efektif karena saat ini masyarakat khususnya anak - anak muda seperti mahasiswa banyak yang telah aktif bergabung menjadi salah satu investor di pasar modal Bursa Efek Indonesia.

\section{Saran}

Peneliti memiliki beberapa saran sebagai masukan agar penyebaran informasi dan promosi yang dilakukan lebih maksimal lagi, seperti Lebih meningkatkan kerjasama dengan berbagai pihak agar program dan promosi yang dijalankan dapat berjalan lebih baik lagi.Kedua, diharapkan Bursa Efek Indonesia semakin berinovasi lagi dalam membuat program promosi yang kreatif dan menarik sehingga 
semakin banyak masyarakat yang tertarik melakukan investasi saham di pasar modal. Diharapkan agar koordinasi antara divisi promosi IDX Channel dan pihak Bursa Efek Indonesia lebih ditingkatkan lagi supaya kegiatan promosi yang dilakukan menjadi semakin efektif untuk disampaikan kepada masyarakat luas.

\section{Daftar Pustaka}

1. Kotler P, Keller KL. Manajemen Pemasaran, Edisi 12. Jakarta: Erlangga. 2012.

2. Alma B. Manajemen Pemasaran dan Pemasaran Jasa. Cetakan Kesembilan. Bandung: Alfabeth. 2011.

3. Kotler P, Armstrong G. Marketing an Introduction. Edisi 10. Indonesia: Perason. 2011.

4. Rangkuti F. Analisis SWOT Teknik Membedah Kasus Bisnis. Jakarta: PT Gramedia Pustaka Utama. 2010.

5. Fauziah AN. Pengaruh Promosi Dan People Terhadap Keputusan Pembelian Konsumen (survey pada café roti gempol dan kopi anjis cabang talaga bodas 46 Bandung).[thesis]. UNPAS: 2016

6. Kotler P, Armstrong G. Prinsip - Prinsip Pemasaran. Edisi 13. Jilid 1. Jakarta: Erlangga.2012.

7. Jefkins F. Periklanan, Edisi Ketiga, Jakarta: Erlangga, 1997.

8. Latar Belakang. [internet] Tersedia di : http:/etd.repository.ugm.ac.id// [diakses pada tanggal 14 Agustus 2017] .

9. Morrisan M.A. Manajamen Media Penyiaran: Strategi Mengelola Radio \& TV. Jakarta: Prenada Media Group. 2009

10. Moloeng LJ. Metodologi Penelitian Kualitatif Edisi Revisi. Bandung: PT Remaja Rosdakarya. 2011.

11. Yin RK. Studi Kasus Desain dan Metode, Jakarta: PT Raja Grafindo Persada. 2012.

12. Morrisan MA. Metode Penelitian Survey. Jakarta: Kencana Prenada Group. 2012

13. IDX.Sejarah. [internet] 2010. Tersedia di:http://www.idx.co.id/id$\mathrm{id} /$ beranda/tentangbei/sejarah.aspx. [diakses pada 09 Januari 2018].
14. IDX. Visi dan Misi. [internet] 2010. Tersedia di: http://www.idx.co.id/id/beranda/tentangbei/visidanmisi.aspx [diakses pada 09 Januari 2018 